Rapid Reviews COVID-19•

\title{
Reviews of: "VALIDATION \\ OF A SALIVA-BASED TEST \\ FOR THE MOLECULAR \\ DIAGNOSIS OF SARS-COV-2 \\ INFECTION"
}

Jianhui Wang, Diana Rose Ranoa ${ }^{1}$

${ }^{1}$ University of Illinois

Published on: Oct 21, 2021

License: Creative Commons Attribution 4.0 International License (CC-BY 4.0). 
To read the original manuscript, click the link above.

Summary of Reviews: This study finds that saliva samples can be used for population screening at a high rate of sensitivity and specificity, supporting other studies already showing that saliva tests can be comparable to NP swabs for COVID-19 testing. While reliable, there are some study flaws.

Reviewer 1 (Jianhui W...) |

Reviewer 2 (Diana Rose R...) | $\square \square \square \square \square$

\section{RR:C19 Strength of Evidence Scale Key}

प्रमप = Misleading

प्र०प्र = Not Informative

प्रा पि = Potentially Informative

प्रीप्र = Reliable

प्राप्र = Strong

To read the reviews, click the links below. 